as intensive care and cardiac surgery to wish to make their own measurements of electrolytes and to buy direct reading ion selective electrodes, which are convenient to use. Routine clinical chemistry laboratories, however, have continued to purchase flame photometers or indirect reading ion selective electrodes, as these instruments generally have a higher capacity. Inevitably, the discordant results from the two systems will give rise to confusion in interpretation.

The solution to this dilemma may be a compromise whereby laboratories will decide to continue to assay most specimens on high capacity indirect reading instruments but will retain a direct reading ion selective electrode to monitor those few patients with pseudohyponatraemia. Clinicians and clinical chemists must understand the problem so that they can select the correct samples for direct reading ion selective electrode measurement without creating an impossibly large workload for the instrument-and they must also realise that the two different types of instruments will give different answers in a small minority of patients.

H G J WORTH

(On behalf of the Scientific Committee,

Top Grade Biochemist,

King's Mill Hospital,

Sutton-in-Ashfield,

Nottinghamshire NG17 4JL

${ }^{1}$ Hald PM. The flame photometer for the measurement of sodium and potassium in biological materials. F Biol Chem 1947;167:499-510.

2 Friedman SM, Wong S-L, Walton JH. Glass electrode measurements of blood sodium and potassium in man. 7 Appl Physiol 1963;18:950-4.

3 Forrest ARW, Shenkin A. Dangerous pseudohyponatraemia. Lancet $1980 ; \mathrm{ii}: 1256$.

- Frier BM, Steer CR, Baird JD, Bloomfield S. Misleading plasma electrolytes in diabetic children with severe hyperlipidaemia. Arch Dis Child $1980 ; 55: 771-5$.

6 Anonymous. Dangerous pseudohyponatraemia. Lancet 1980;ii:1121.

- Marks V. Clinical biochemistry nearer the patient. Br Med $\mathcal{F} 1983 ; 286$ : 1166-7.

\section{Rotavirus in the home and hospital nursery}

Rotaviruses cause most of the severe diarrhoeal illness in children between the ages of 6-9 months and 2 years. By contrast, rotavirus infection in neonates-even in premature infants-is mild. ${ }^{1-4}$ In this, the human infant differs appreciably from the young farm animal, where the younger the animal the more severe the disease; thus for piglets under a week old there is a high mortality from rotavirus infection. A weaning piglet, however, although it may become ill and lose weight, is much less likely to die of the infection. The same applies to calves and lambs. This discrepancy may be explained by the fact that in man maternal antibodies cross the placenta and may confer protection to the neonate. Calves, pigs, and lambs acquire no such antibody from their mothers and have, to rely on antibody in colostrum to protect them from infection.

Children who become infected with rotavirus while they are in hospital usually recover in about eight days and then go home. Possibly these children excrete rotavirus at a later stage, although, until recently, this has been described only in children who are immunocompromised. A second episode of excretion has recently been described by Dearlove et al. ${ }^{5}$ The second infection may have been caused by a different serotype of rotavirus; but previous accounts of endemic infection by rotaviruses in special care baby units of maternity hospitals have all found that the same strain of virus appeared to be "resident" in the hospital and that the strains which were present in the community were not encountered in the nurseries and special care baby units. ${ }^{3} 4$

Once rotaviruses become established within a hospital nursery they are difficult to eradicate. This is not surprising, since viruses survive for days or even weeks on an impervious surface at high or low humidities (though not so well at intermediate humidities) and at ordinary temperatures. ${ }^{6}$ Viruses are excreted in faeces in enormous numbers $-100 \times 10^{9}$ virus particles/g faeces is not unusual. Thus the most exceptional care is required to prevent their transfer from baby to baby, via nurses' hands or on other contaminated articles. Wiping a surface with disinfectant may reduce the infective count by a millionfold but is of little avail if there are ten thousand million particles.

Experience suggests that the only way of eradicating rotavirus from the hospital nursery is to stop admissions to that particular unit until all the mothers and babies in it have gone home. Once the infected unit is empty, it may be disinfected by spray and formaldehyde fumigation and after 10 days or so the staff, provided they are still healthy, can return to ordinary duty.

Episodes of endemic diarrhoea in maternity hospitals, often going on for months, have so far been described only in major centres where the laboratory is able to detect the causative virus. ${ }^{7}$ This sort of infection may be common but underdiagnosed, because until recently the ability to screen for viral infections has been limited. Now that enzyme-linked immunosorbent assay and other diagnostic tests-for example, reverse passive haemagglutination ${ }^{8}$-are becoming generally available, we may expect that many more examples will be reported.

Rotavirus infection in babies, whether symptomatic or asymptomatic, causes them to lose weight. In developed countries this probably does not matter, since the babies soon make it up again. In poor conditions in the tropics, however, Mata $e t ~ a l^{9}$ showed that repeated episodes of diarrhoea caused young children to lose weight to the extent that they never made it up, so that their final growth was stunted.

Children are great disseminators of infection, and so it is not surprising that Grimwood et al (p 575) find that they are the principal spreaders of rotaviruses within families. Although almost every child has antibodies against rotavirus by the age of $5,{ }^{10}$ infections in adults do occur, especially in old people's homes. In one study ${ }^{11}$ antibody titres to one serotype of rotavirus were found to be highest around the age of 10 , and slowly diminished thereafter, so that in people over 80 they were sometimes undetectable. Outbreaks of infection in geriatric units have been described by several authors. ${ }^{1012} 13$

At least four serotypes of rotaviruses are now recognised, ${ }^{14}$ which fall into two or perhaps three subgroups. ${ }^{15}$ Studies in animals have shown that infection by one rotavirus serotype does not protect against infection by a rotavirus of a different serotype. ${ }^{16}$ Most adults will have had some previous contact with most serotypes of rotavirus and are therefore unlikely to be as susceptible to infection as children. In one study, however; in an isolated tribe of South Américan Indians, ${ }^{17}$ when a rotavirus of a serotype to which none of the tribe had been exposed was introduced, people of all ages developed symptoms. Prevention must be important, a live attenuated vaccine might help, ${ }^{18}{ }^{19}$ but there are many difficulties to be overcome before such a vaccine becomes available.

Consultant Virologist,

T H FleweTt

Regional Virus Laboratory

East Birmingham Hospital,

Birmingham B9 5ST 
' Albrey MB, Murphy AM. Rotaviruses and acute gastroenteritis of infants and children. Med $\mathcal{f}$ Aust 1976;i:82-5.

${ }^{2}$ Chrystie IL, Totterdell BM, Banatvala JE. Asymptomatic endemic rotavirus infections in the newborn. Lancet 1978; i:1176-8.

${ }^{3}$ Bryden AS, Thouless ME, Hall CJ, et al. Rotavirus infections in a specialcare baby unit. Fournal of Infection 1982;4:43-8.

- Rodger SM, Bishop RF, Birch C, McLean B, Holmes IH. Molecular epidemiology of human rotaviruses in Melbourne, Australia, from 1973 to 1979 , as determined by electrophoresis of genome ribonucleic acid. f Clin Microbiol $1981 ; \mathbf{1 3}: 272-8$.

- Dearlove J, Latham P, Dearlove B, Pearl K, Thomson A, Lewis IG. Clinical range of neonatal rotavirus gastroenteritis. $\mathrm{Br} \mathrm{Med} \mathrm{f} \mathrm{1983;286}$ 1473-5.

6 Moe K, Shirley JA. The effects of relative humidity and temperature on the survival of human rotavirus in faeces. Arch Virol 1982;72:179-86.

7 Totterdell BM, Chrystie IL, Banatvala JE. Cord blood and breast-milk antibodies in neonatal rotavirus infection. $\mathrm{Br} M$ ed $\mathcal{F} 1980 ; \mathbf{2 8 0}: 282-30$.

* Sanekata ' $T$, Yoshida Y, Oda K, Okada H. Detection of rotavirus antibody by inhibition of reverse passive hemagglutination. 7 Clin Microbiol 1982 ; $15: 148-55$.

9 Mata LJ, Kronmal RA, Garcia B, Butler W, Urrutia JJ, Murillo S. Breast-feeding, weaning and the diarrhoeal syndrome in a Guatemalan Indian village. In: Acute diarrhoea in childhood. Amsterdam: Elsevier, Excerpta Medica, North Holland, 1976:311-38. (Ciba Foundation symposium (new series), No 42.)

${ }^{10}$ Flewett $\mathrm{TH}$. Clinical features of rotavirus infection. In: Tyrrell AJ, Kapikian AZ, eds. Virus infections of the gastrointestinal tract. New York Marcel Dekker, 1982:125-45.

11 Elias MM. Distribution and titres of rotavirus antibodies in different age groups. f Hyg (Lond) 1977;79:365-72.

1: Orstavik I, Haug KW, Søvde A. Rotavirus-associated gastroenteritis in two adults probably caused by virus reinfection. Scand $\mathcal{F}$ Infect Dis 1976 $8: 277-8$.

13 Cubitt WD, Holzel $\mathrm{H}$. An outbreak of rotavirus infection in a long-stay ward of a geriatric hospital. F Clin Pathol $1980 ; 33: 306-8$.

14 Sato K, Inaba Y, Miura Y, Tokuhisa S, Matumoto M. Antigenic relationships between rotaviruses from different species as studied by neutralization and immunofluorescence. Arch Virol 1982;73:45-50.

15 Zissis G, Lambert JP, Kapsenberg JG, Enders G, Mutanda LN. Human rotavirus serotypes. Lancet 1981 ; i :944-5.

is Gaul SK, Simpson TF, Woode GN, Fulton RW. Antigenic relationships among some animal rotaviruses: virus neutralization in vitro and crossprotection in piglets. $\mathcal{F}$ Clin Microbiol $1982 ; \mathbf{1 6}: 495-503$

17 Linhares AC, Pinheiro FP, Freitas RB, Gabbay YB, Shirley JA, Beards GM. An outbreak of rotavirus diarrhea among a nonimmune, isolated South American Indian community. Am f Epidemiol 1981;113:703-10.

is Kapikian AZ, Wyatt RG, Greenberg HB, et al. Approaches to immunization of infants and young children against gastroenteritis due to rotaviruses. Rev Infect Dis 1980;2:459-69.

19 Flewett TH. New prospects for control of virus diarrhoea in children. $\mathcal{F} R$ Soc Med $1982 ; 75: 493-4$.

\section{Questions on clinical trials}

In private, medical scientists will admit that therapeutic research has had a poor record over the past two decades. Far too many questions about the value of treatment that were being asked in the early 1960s remain unanswered. For rheumatologists the outstanding problem is whether any of the available drugs really do slow down the disease process in rheumatoid arthritis.

Among the reasons that that question is still unanswered are the poor design of many clinical trials and the futile planning of many medical conferences. No one gains from and much time is wasted by meetings at which speakers read boring accounts of poor studies to audiences assembled for other motives, with little if any time for discussion.

Against that background, I was pleased to attend a meeting held at the London Hospital earlier this year (and now reported in a supplement ${ }^{1}$ to the British Fournal of Rheumatology). The meeting had only a few, commendably brief papers and most of the participants' time was spent in small workshops. Furthermore, the final session produced some clear conclusions and some more general opinions.

As an editor faced each year with the task of reading and assessing dozens of clinical trials I found myself in strong agreement with Richard Peto: a good trial should ask an important question and answer it reliably. Peto, the "big wing" man of trial design, believes that most good trials need to be very large or to have a long period of treatment or bothan approach vindicated by the contrast between the inconclusive results of early, small trials of beta blockers in coronary heart disease and the clear evidence of a small but important effect that emerged from the massive later studies.

One of the main reasons that the beta blocker studies convinced the sceptics was that the measure chosen was deathas "objective" and "hard" an end point as anyone could want. Rheumatoid arthritis provides no such clear measure-indeed, as Verna Wright reminded the meeting, clinicians may all too easily spend years writing "doing well" in the notes of a patient who has become progressively more crippled before their eyes. What matters to patients is the effects on their daily life of their damaged joints, and the account by J F Fries of the Stanford Arthritis Center Health Assessment Questionnaire ${ }^{2}$ suggested that a self administered questionnaire may be one workable method of measuring the extent of an individual's disability and of repeating that assessment at intervals. Typical of the questions asked are "Are you able to open jars which have been previously opened?" and "Are you able to bend down to pick up clothing from the floor ?" When combined with a scoring system a questionnaire of this kind gives a good measure of features of practical importance to the patient. Indeed, one of the conclusions reached at the meeting was that patients should be encouraged to take more part in deciding the objectives of treatment.

So the way forward for rheumatologists seems to lie in better designed, better organised trials, probably larger and multicentre, and certainly using assessment methods that are reproducible, simple, and relevant to the patients' problems. Clinicians in other disciplines might usefully ask themselves similar questions to those posed at the London Hospital.

TONY SMITH

Deputy Editor,

$B M \mathcal{F}$

1 Chaput de Saintonge DM, Joyce CRB, Currey HLF, Kirwan JR. Advances in assessing rheumatoid arthritis. British fournal of Rheumatology 1983:22, suppl:1-97.

2 Fries JF, Spitz PW, Young DY. The dimensions of health outcomes: the health assessment questionnaire, disability and pain scales. $\mathcal{F}$ Rheumatol $1982 ; 9: 789-93$

\section{Latissimus dorsi reconstruction of the breast}

The latissimus dorsi is a large triangular muscle taking its origin from the lower thoracic and lumbar vertebrae, and from the posterior crest of the ilium. As it sweeps along the posterior wall of the axilla to be inserted into the bicipital groove of the humerus the muscle narrows considerably. The skin overlying the latissimus dorsi muscle is adequately supplied by perforating blood vessels from the muscle itself, and, conveniently for reconstructive purposes, the dominant nerve and blood supply of the muscle (the subscapular neurovascular bundle) enters its deep surface in the axilla. These anatomical features make it possible for the whole muscle origin, with an 